\title{
The Effect of some Dietary Medicinal Herbal Extracts on Growth Performance and Economic Efficiency of Nile Tilapia
}

\author{
Sadek, M. F. A. \\ Department of Animal Production, Faculty of Agriculture, Fayoum University, Egypt
}

Received: $4 / 7 / 2020$

\begin{abstract}
This experiment was performed to study the effect of ginger and licorice extracts on to the diets on growth performance, feed utilization and economic efficiency besides water and fish quality. The experiment started at 15 May to 15 September 2019 for a period of 120 days at a private fish farm in Fayoum Governorate, Egypt. 1680 monosex Nile tilapia (Oreochromis niloticus) fingerlings with an average weight of $18.26 \mathrm{~g} \pm 0.34$ have been randomly distributed in 12 net hapa in six experimental groups $\left(4 \times 7 \times 1.5 \mathrm{~m}\right.$ with a water volume of $28 \mathrm{~m}^{3}$ and 140 fingerlings $)$ suspended in an earthen pond. The diets was $\left(\mathrm{T}_{1}\right)$ control group, fed on the basal diet only; $\mathrm{T}_{2}$ and $\mathrm{T} 3$ the basal diet sprayed with aqueous ginger extract at a rate of 2 and $4 \mathrm{ml} / \mathrm{kg}$ feed; $\mathrm{T}_{4}$ and $\mathrm{T} 5$ the basal diet sprayed with aqueous licorice extract at a rate of 2 and $4 \mathrm{ml} / \mathrm{kg}$ feed and $\mathrm{T}_{6}$ mix group, fed on the basal diet sprayed with 2 ml ginger plus 2 $\mathrm{ml}$ licorice aqueous extracts $/ \mathrm{kg}$ feed. The results showed that ginger and licorice extract supplements were able to minimize heavy metal accumulation in the body of the fish (levels of cadmium, lead and copper) Special to expand adding. While $4 \mathrm{ml}$ of licorice or ginger was better than $2 \mathrm{ml}$ and combining extract better than both. Fish fed mixed diet (T6) achieved the best significant final body weight followed by dietary fish groups (T5), (T4), (T3) and (T2), respectively, Whereas control group (T1) obtained the lowest values. The best FCR and higher levels of feed intake (FI), protein efficiency ratio and PPV were obtained when fish were fed on T6 diet. Which the best significant values in all parameters. T6 showed significantly higher net yields and economic efficiency compared with other tested diets. While control diets $\mathrm{T} 1$ had the least economic output significantly $(\mathrm{P} \leq 0.05)$.
\end{abstract}

Keywords: Nile tilapia, ginger, licorice, extract, growth performance, feed utilization and water quality

\section{INTRODUCTION}

Overall, aquaculture remains one of the fastest growing food-producing sectors and acts 46.8 per cent from global fish production. Tilapias are reportedly the second-largest group of farmed finfishes in freshwater aquaculture just after carps (FAO, 2018). In recent years, fish farming in Egypt has developed at a rapid rate, and tilapia have increased in intensive systems, and Egypt producing 1,935 million tons, 80.1 percent from farming (GAFRD, 2018). Fish farming in Egypt is legally dependent on drainage water being used for farming. This water carries a lot of pollutants which affect fish health and low growth.

Agriculture and other terrestrial activities are potential sources of contamination by heavy metals. Several studies indicated varying levels of contamination in Egypt by one or more heavy metals of fish farms (Abumourad et al., 2013; Alm Eldeen et al., 2018; Hamada et al., 2018; Khallaf et al., 2018). To boost the fishing community in order to benefit economically from intensive farming systems, farmers use synthetic antibiotics and other chemotherapy drugs to preserve the health of farmed fish.

Many researched in aquaculture, use natural materials as alternatives to synthetic drugs. Medicinal herbal extracts provide useful biologically active metabolites with different benefits including immune modulation (Zanuzzo et al., 2015; Yang et al., 2015; Yilmaz and Ergün, 2018; Yilmaz, 2019a, 2019b), Promoting growth, enhancing antioxidants, antidepressants, enhancing digestion, stimulating effects of appetite (Zhang et al., 2010; Mahdavi et al., 2013; Gabriel et al., 2015), and hepatoprotective reactions (Gurkan et al., 2015; Yilmaz et al., 2014), If handled properly. Another explanation is that herbal medicinal

\footnotetext{
*Corresponding author e-mail: mfa02@fayoum.edu.eg
}

extracts are readily accessible, cheaper and appear to be more biodegradable than synthetic drugs (Olusola et al., 2013; Reverter et al., 2014).

Ginger (Zingiber officinale) is one of the best known spices in the world, and its health benefits have also been used widely throughout the past. The dried ginger extract includes both monoterpenes and sesquiterpenes. For ginger, the phenolic compounds are primarily gingerols, shogaols, and paradols. Gingerols are the major polyphenols in fresh ginger, such as 6gingerol, 8-gingerol and 10-gingerol (Prasad and Tyagi, 2015). Gingerols and shogaols and some related phenolic ketone derivatives are the principal active antioxidant principles in ginger (Cao et al., 1993). Ginger has been found to have biological activities in recent years, such as antioxidants, anti-inflammatory and antimicrobials (Siegel et al., 2014). Ginger has been shown to improve immunity and increase growth in various fish species such as tilapia Oreochromis mossambicus, (Immanuel et al., 2009), maintain tissue morphology and function, and strengthen tissue damage after Nile tilapia infection (Brum et al., 2018). Similar beneficial functions in yellow perch Perca flavescens, (Elabd et al., 2016) and carp (Dubey and Chauhan, 2018) were approved using licorice.

Licorice extract, one of the herbal medicines commonly used for a number of purposes, including gastric ulcer treatment, is a mixture of several constituents known as having a wide range of beneficial effects, including anti-inflammatory activity (Baltina, 2003). The principal compound of licorice extract is triterpene glycyrrhizin it is believed that it acts as an anti-inflammatory (Braca et al., 2002). A significant number of components were extracted from the roots of licorice such as starches, polysaccharides, simple 
sugars, amino acids, mineral salts, essential oil, fat, asparagines, carbohydrates, sterols, volatile oils and other substances. The licorice found to contain essential phytoconstituents such as glycyrrhizine, glycyrrhizinic acid, glabrin A and B, and isoflavones. This is used primarily as an anti-inflammatory, anti-bacterial, antifungal, anti-diabetic, antiviral, anti-ulcer, anti-causing, anti-oxidant, and anti-diuretic; skin whitening (Damle, 2014). In addition, licorice protected the common carp liver from damage caused by carbon tetrachloride (Yin et al., 2011) and adapted the regulatory ion pathway in rainbow trout gills that were exposed to ion-poor water (Chen et al., 2015 and 2016).

\section{MATERIALS AND METHODS}

The experiment started at 15 May 2019 at a private fish farm located in Fayoum Governorate, Egypt and continued for 120 days. 1680 monosex Nile tilapia (O. niloticus) fingerlings with an average weight of $18.26 \pm 0.34 \mathrm{~g}$ were randomly distributed in six experimental groups in 12 net hapa $(4 \times 7 \times 1.5 \mathrm{~m}$, a water volume area was $28 \mathrm{~m}^{3}$, water depth was $1 \mathrm{~m} /$ hapa and 140 fingerlings) suspended in an earthen pond with an area of $4050 \mathrm{~m}^{2}$. Approximately $10-15 \%$ of the water from the pond was drained off and replenished every day through the entry of fresh water. Fish earned experimental diets following 15 days of adaptation to the pond conditions as follows.

$\left(\mathrm{T}_{1}\right)$ control group, fed on the basal diet only (Tables 1 and 2); $\left(\mathrm{T}_{2}\right)$ the basal diet sprayed with aqueous ginger extract at a rate of $2 \mathrm{ml} / \mathrm{kg}$ feed; $\left(\mathrm{T}_{3}\right)$ the basal diet sprayed with aqueous ginger extract at a rate of $4 \mathrm{ml} / \mathrm{kg}$ feed; $\left(\mathrm{T}_{4}\right)$ the basal diet sprayed with aqueous licorice extract at a rate of $2 \mathrm{ml} / \mathrm{kg}$ feed; $\left(\mathrm{T}_{5}\right)$ the basal diet sprayed with aqueous licorice extract at a rate of $4 \mathrm{ml} / \mathrm{kg}$ feed and $\left(\mathrm{T}_{6}\right)$ mix group, fed on the basal diet sprayed with $2 \mathrm{ml}$ ginger plus $2 \mathrm{ml}$ licorice aqueous extracts $/ \mathrm{kg}$ feed. The diet prepared by dissolved herbal extract in $100 \mathrm{~cm}$ ethyl alcohol and then sprinkled on the diet at night and stirred well then fed on the next day for a week and repeating this process weekly until the experiment is complete. Herbal extracts were obtained from private market (Medicinal herbal and their extract markets). Fish were handfed twice daily (09:00 a.m. and 02:00 p.m.) at a rate of 5\% of BW for 6 days/week. The feed amount was adjusted biweekly according to the fish body weight.

The initial body weight was recorded at the beginning of the experiment. All fish were collected biweekly from each replicate in each group during the 4-month experimental period and growth performance for each treatment group was recorded individual body weight, body weight gain, feed intake and feed conversion ratio.

\section{Determination of Heavy metals}

At the end of the experiment, 10 fish from each experimental group (five fish per replicate) were taken randomly to test the residual heavy metals (cadmium, lead, and copper) in fish flesh and pond water. The determination was carried out at the Environmental and Food Pollutants Laboratory, Faculty of Agriculture, Fayoum University. It was as follows:
Table (1): Composition and proximate analysis of basal diet

\begin{tabular}{lc}
\hline Item & Composition \\
\hline Fish meal & 20 \\
Soybean & 27 \\
Corn & 25 \\
Rice bran & 20 \\
Linseed & 3 \\
Vitamin premix ${ }^{1}$ & 2 \\
Di-calcium Phosphate & 1 \\
Limestone & 1 \\
Binder (inert) & 1 \\
TOTAL & 100 \\
\hline & \\
\hline Dry matter & 89.77 \\
Crud protein & 30.16 \\
Lipid & 9.92 \\
Crud fiber & 6.16 \\
Ash & 8.51 \\
NFE & 45.25 \\
GE MJ/kg & 20.14 \\
GE, Kcal/g & 4.810 \\
COST/kg & 8.90 \\
\hline I Each kg conalysis \% & \\
\hline
\end{tabular}

1: Each kg contains 100000 IU vit. A, 200000 IU vit. D3, $1000 \mathrm{mg}$ vit $\mathrm{K} 3,1500 \mathrm{mg}$ vit $\mathrm{c}, 1600 \mathrm{mg} \mathrm{Cu}, 156 \mathrm{mg} \mathrm{I}$, $6421 \mathrm{mg} \mathrm{Fe}, 12800 \mathrm{mg} \mathrm{Mn}, 9000 \mathrm{mg} \mathrm{Zn}, 32 \mathrm{mg} \mathrm{Se}, 53$ mg cobalt.

2: Nitrogen free extract $($ NFE \%) $=100-$ Crude protein Crude lipid - Crude fiber - Crude ash.

3: Gross energy was calculated according to NRC (1993) as $5.65,9.45$, and $4.11 \mathrm{kcal} / \mathrm{g}$ for crude protein, crude fat, and carbohydrates, respectively

Table (2): Amino acids analysis of basal diet

\begin{tabular}{lccc}
\hline & & \multicolumn{2}{c}{$\begin{array}{c}\text { Amino acids } \\
\text { requirements }\end{array}$} \\
\cline { 3 - 4 } Amino acids & In diet & $\begin{array}{c}\text { Ogino, } \\
\mathbf{1 9 8 0}\end{array}$ & $\begin{array}{c}\text { NRC } \\
\mathbf{1 9 9 3}\end{array}$ \\
\hline Arginine\% & 2.46 & 1.37 & 1.18 \\
Histidine\% & 0.81 & 0.63 & 0.48 \\
Isoleucine\% & 1.42 & 1.12 & 0.87 \\
Leucine\% & 2.54 & 1.68 & 0.95 \\
Lysine\% & 2.21 & 1.63 & 1.43 \\
Methionine\% & 0.69 & 0.51 & 0.75 \\
Phenylalanine\% & 1.47 & 1.04 & 1.05 \\
Threonine\% & 1.40 & 0.99 & 1.05 \\
Tryptophan\% & 0.33 & 0.35 & 0.28 \\
Valine\% & 1.64 & 1.26 & 0.78 \\
\hline
\end{tabular}

\section{Sample preparation}

Samples were ground and approximately $0.2-0.3 \mathrm{~g}$ of sample was weighed and added into the polytetrafluoro-ethylene digestion vessel with $5 \mathrm{~mL}$ of concentrated $\mathrm{HNO}_{3}$ and $2 \mathrm{~mL}$ of hydrogen peroxide 
$\left(\mathrm{H}_{2} \mathrm{O}_{2}\right)$. Subsequently, the samples were digested using a two-step temperature program. During the first step, the temperature was linearly increased to $190^{\circ}$ Cover 10 minutes; the maximum power of the rotating magnetron was $1000 \mathrm{~W}$. During the second step, the temperature was maintained at $190^{\circ} \mathrm{C}$ for 30 minutes. After digestion and cooling, each solution was evaporated to $\sim 2 \mathrm{~mL}$ and diluted with deionized water in a $50-\mathrm{mL}$ volumetric flask for the AAS analysis. The results were reported as the average of three repeated measurements, and all digestions were conducted in triplicate.

\section{Instruments}

An Agilent atomic absorption spectrometer equipped with Agilent single-element hollow cathode lamps and a $10-\mathrm{cm}$ air-acetylene burner was used for the determination of the metal ions. All instrumental settings were those recommended in the manufacturer's manual book that is given in Table (3).

Table (3): Instrumental conditions for flame atomic absorption spectrometer

\begin{tabular}{lccc}
\hline Element & $\begin{array}{c}\text { Wavelength } \\
(\mathbf{n m})\end{array}$ & $\begin{array}{c}\text { Slit width } \\
(\mathbf{n m})\end{array}$ & $\begin{array}{c}\text { Lamp } \\
\text { Current (mA) }\end{array}$ \\
\hline $\mathbf{F e}$ & 248.3 & 0.2 & 30 \\
$\mathbf{P b}$ & 283.3 & 0.7 & 15 \\
$\mathbf{N i}$ & 232.0 & 0.2 & 30 \\
$\mathbf{C o}$ & 240.7 & 0.2 & 30 \\
$\mathbf{C d}$ & 228.8 & 0.7 & 12 \\
$\mathbf{C u}$ & 324.8 & 0.7 & 15 \\
\hline
\end{tabular}

Water quality parameters

Water temperature, $\mathrm{PH}$ and dissolved oxygen (DO) throughout experimental periods were measured by centigrade thermometer, Orion digital $\mathrm{pH}$ meter model 201 and oxygen meter, (Cole Parmer model 5946).

Fish growth performance and feed nutritive value calculation

The growth performance of fish was calculated according to the following equations: Total gain (TG), $g$ $=\mathrm{W} 2-\mathrm{W} 1$, Where $\mathrm{W} 2$ is the final body weight; $\mathrm{W} 1$ is initial body weight. Specific growth rate (SGR) $\%=100$ (Ln W2 - Ln W1)/T, Where W2: final weight, W1: initial weight, Ln: natural $\log , \mathrm{T}$ : is the time in days. Daily gain (DG), $\mathrm{g}=\mathrm{TG}(\mathrm{g}) /$ Experimental period (day). Survival rate $\%=100$ (number of fish at the end of experiment) / (Number of fish at the beginning of experiment). Feed conversion ratio $(\mathrm{FCR})=$ total feed consumption (g)/ (w2-w1). Protein efficiency ratio $($ PER $)=$ Weight gain, g / Protein intake, g. Protein productive value (PPV) \%=100 (Retained protein, g / Protein intake, g).

\section{Proximate chemical analysis}

Proximate chemical analysis of diets was carried out according to the standard methods AOAC (1995) for dry matter, crude protein, crude fiber, and ash. Nitrogen-free extract was calculated by difference. Gross energy content of the experimental diets was calculated using factors of $5.65,9.45$, and $4.11 \mathrm{kcal} / \mathrm{g}$ of crude protein, crude fat and carbohydrates, respectively NRC (1993).

\section{Economic efficiency}

The following equations were used: Total feed costs per treatment $=$ feed cost per $1 \mathrm{~kg}$ diet $\times$ feed intake. Total outputs per treatment, LE $=$ fish price $\times$ total fish production. Net return per treatment (LE) $=$ total outputs - total costs. Economic efficiency per treatment $(\%)=($ net return/total costs $) \times 100$.

\section{Statistical analysis}

All data were analyzed using the Statistical Package for the Social Sciences (SPSS) 21.0 statistical software. A one-way analysis of variance (ANOVA) and Duncan's multiple range tests were used to determine the statistical significance among groups. The significant differences were determined at the level of $\mathrm{P} \leq .05$.

\section{RESULTS AND DISCUSSION}

\section{Water and fish quality}

Table (4) clarified the parameters of water quality such as temperature, dissolved oxygen and $\mathrm{pH}$ next to the concentration of heavy metals in pond water and at the end of the fish flesh. It has been observed that parameters in the appropriate range for tilapia production alongside ginger and licorice extract supplements have been able to decrease heavy metal accumulation in the special body of the fish to increase the addition, whereas $4 \mathrm{ml}$ of licorice or ginger was better than $2 \mathrm{ml}$ and mix extract was better than all; cadmium, lead and copper levels in the water of the pond were higher than the permissible limit (AbdelMohsien and Mahmoud, 2015; Kaoud and El-Dahshan, 2010; Niemiec and Wiśniowska-Kielian, 2015), due to using the agricultural drainage water in which heavy metals and pesticides are the main pollutants according to Kalay and Canli (2000). Our results come in accordance with the previous studies which indicated that ginger declined the cadmium accumulation in the liver and kidney and improved their functions (Egwurugwu et al., 2007; Gehan and Ayman, 2010). Thus water quality improved and fish quality too.

\section{Growth performance:}

Table (5) show growth performance of fish fed the experimental diets. The findings showed that the fish diets containing ginger and licorice showed a substantial improvement $(\mathrm{P}<0.05)$ in total final body weight, weight gain, specific growth rate $\%$ and survival rate.

The nutritional treatment $\left(\mathrm{T}_{6}\right)$, which includes both ginger and licorice, recorded the highest body weight followed by $\mathrm{T}_{5}, \mathrm{~T}_{4}, \mathrm{~T}_{3}$ and $\mathrm{T} 2$, respectively, while the lowest estimates were obtained by basal group $\left(T_{1}\right)$. A similar trend followed with regard to body weight gain, specific growth rate percent and survival rate. These results clearly showed that the dose-dependent response of the licorice and ginger stimulated fish growth may be to the supplementation of licorice and ginger. 
Table (4): Effect of ginger and licorice extract on water and fish quality

\begin{tabular}{|c|c|c|c|c|c|c|c|}
\hline \multirow{2}{*}{ Measurement } & \multirow{2}{*}{ Pond water } & \multicolumn{6}{|c|}{ Fish flesh (ppm) } \\
\hline & & $\mathbf{T}_{1}$ & $\mathbf{T}_{2}$ & $\mathbf{T}_{\mathbf{3}}$ & $\mathbf{T}_{4}$ & $T_{5}$ & $T_{6}$ \\
\hline Temperature ${ }^{\circ} \mathrm{C}$ & Average (29) & & & & & & \\
\hline $\mathbf{P h}$ & 7.22 & & & & & & \\
\hline DO (mg/l) & 4.85 & & & & & & \\
\hline \multicolumn{8}{|l|}{ Heavy metal (ppm) } \\
\hline Cadmium & 0.0235 & 0.297 & 0.214 & 0.198 & 0.172 & 0.115 & 0.075 \\
\hline Copper & 0.0351 & 0.670 & 0.265 & Nil & 0.465 & 0.412 & 0.081 \\
\hline Lead & 0.0321 & 1.511 & 0.863 & 0.678 & 0.824 & 0.698 & 0.383 \\
\hline \multicolumn{8}{|c|}{$\begin{array}{l}\text { Permissible limits in pond water and Fish flesh (ppm) according to Abdel-Mohsien and Mahmoud (2015), Kaoud } \\
\text { and El-Dahshan (2010) and Niemiec and Wiśniowska-Kielian (2015) }\end{array}$} \\
\hline Measurement & \multicolumn{3}{|c|}{ Pond water } & \multicolumn{4}{|c|}{ Fish flesh (ppm) } \\
\hline Temperature $^{\circ} \mathrm{C}$ & \multicolumn{2}{|r|}{$20-30$} & & & & & \\
\hline pH & \multicolumn{2}{|r|}{$6-9$} & & & & & \\
\hline DO (mg/l) & & $>$ & & & & & \\
\hline Heavy metal (ppm) & \multicolumn{2}{|r|}{$>$} & & & & & \\
\hline Cadmium & \multicolumn{3}{|c|}{$0.001-0.082$} & \multicolumn{4}{|c|}{$0.05-1.0$} \\
\hline Copper & \multicolumn{3}{|c|}{$0.044-0.887$} & \multicolumn{4}{|c|}{1.00} \\
\hline Lead & \multicolumn{3}{|c|}{$0.04-0.29$} & \multicolumn{4}{|c|}{$0.1-0.5$} \\
\hline
\end{tabular}

The improved growth of Nile tilapia (O. niloticus) may be caused by its digestibility and stimulating effect by its aromatic substances or essential oils extracted from its roots and leaves. In addition, the enhancement of body weight gain is relates the active materials found in plant extracts, resulting in increased feed utilization efficiency, resulting in increased growth. Ginger (Zingiber officinale) and licorice (Glycyrrhiza glabra) are two herbal extracts with promising properties for aquaculture as functional feed (Shakya, 2015; Smith et al., 2018; Tiwari et al., 2018 and Mohammed et al., 2020).
Improved fish immunity and increased growth rates by adding ginger to their diets, proven by many researchers, including tilapia (Immanuel et al., 2009), carp (Sukumaran et al., 2016), European sturgeon (Kanani et al., 2014), Asian sea bass (Talpur et al., 2013), Rainbow trout (Nya and Austin, 2009; Shaluei et al., 2016) and grouper (Amar et al., 2018). Lee et al. (2016) stated that a higher weight gain and SGR compared to the control diet was achieved by the use of ginger powder in juvenile rockfish diet. Also ginger extract dietary supplementation maintained tissue morphology and function and improved tissue damage after infection in Nile tilapia (Brum et al., 2018).

Table (5): Effect of ginger and licorice extract on the growth performance of Nile tilapia

\begin{tabular}{|c|c|c|c|c|c|c|c|}
\hline \multirow{2}{*}{ Items } & \multicolumn{6}{|c|}{ Medicinal extracts } & \multirow{2}{*}{ SED* } \\
\hline & $\mathbf{T}_{1}$ & $\mathbf{T}_{2}$ & $\mathbf{T}_{3}$ & $\mathbf{T}_{4}$ & $\mathbf{T}_{\mathbf{5}}$ & $\mathbf{T}_{6}$ & \\
\hline Initial weight (g) & 19.35 & 17.40 & 17.50 & 19.45 & 17.65 & 18.20 & 1.084 \\
\hline Final weight (g) & $163.60^{\mathrm{d}}$ & $177.85^{\mathrm{c}}$ & $187.90^{\mathrm{bc}}$ & $192.90^{\mathrm{b}}$ & $197.75^{\mathrm{ab}}$ & $208.05^{\mathrm{a}}$ & 5.560 \\
\hline Total weight gain (g) & $144.25^{\mathrm{d}}$ & $160.45^{\mathrm{c}}$ & $170.40^{\mathrm{bc}}$ & $173.45^{\mathrm{b}}$ & $180.10^{\mathrm{ab}}$ & $189.85^{\mathrm{a}}$ & 4.853 \\
\hline Daily gain (g/day) & $1.20^{\mathrm{d}}$ & $1.34^{\mathrm{c}}$ & $1.42^{\mathrm{bc}}$ & $1.45^{\mathrm{b}}$ & $1.50^{\mathrm{ab}}$ & $1.58^{\mathrm{a}}$ & 0.040 \\
\hline SGR (\%/day) & $1.78^{\mathrm{d}}$ & $1.94^{\mathrm{bc}}$ & $1.98^{\mathrm{abc}}$ & $1.91^{\mathrm{c}}$ & $2.01^{\mathrm{ab}}$ & $2.03^{\mathrm{a}}$ & 0.037 \\
\hline Survival, \% & $90.67^{\mathrm{c}}$ & $94.00^{\mathrm{ab}}$ & $93.00^{\mathrm{ab}}$ & $95.00^{\mathrm{a}}$ & $93.00^{\mathrm{ab}}$ & $96.00^{\mathrm{a}}$ & 1.319 \\
\hline
\end{tabular}




\section{Feed utilization}

Feed intake increased significantly, whereas feed conversion ratio (FCR) improved with diets supplemented with extracted (Table 6). Moreover, protein efficiency ratio and protein productive value (PPV) values increased significantly with present extracts in diets. Increased feed intake resulted from high nutritional demand with stimulated production, or from increased appetite due to sensory enhancement resulting from the inclusion of ginger and licorice extracts in diets.

The best FCR and higher levels of feed intake (FI, protein efficiency ratio and PPV were obtained with (T6) which the best significant values in all parameters followed by $\left(\mathrm{T}_{5}\right),\left(\mathrm{T}_{4}\right),\left(\mathrm{T}_{3}\right)$ and $\left(\mathrm{T}_{2}\right)$, respectively, While the worst values were recorded with control group $\left(T_{1}\right)$. Nya and Austin (2009) reported that the diet containing different level of ginger powder improved feed conversion and protein efficiency of rainbow trout in the feeding trial.
Al saiad and Al-Zayat (2019) check the impact of inclosing of different ginger levels in diet on growth performance, body composition, and cost benefit analysis, feed and nutrient utilization, of Nile tilapia $O$. niloticus. The results showed that the best feed conversion ratio (FCR), protein efficiently ratio (PER), and protein productive value (PPV) was found when fish were fed the diet containing $0.5 \%$, and $1 \%$ Ginger extract. With regard to Licorice extract Sirakov et al (2019) studied the impact of feed supplemented with licorice on growth efficiency, blood parameters and rainbow trout quality (Oncorhynchus mykiss W.) with supplementation of $300 \mathrm{mg} / \mathrm{kg}^{-1}$ licorice in pellets. They found an improvement in specific growth rate and feed utilization compared to the basal diet.

Higher values of growth performance and feed utilization in (T6) may return The combined effect of both ginger and licorice, Mixing ginger And licorice together one diet led to Raising the liveliness of fish Which reflected on growth performance.

Table (6): Effect of ginger and licorice extract on feed utilization of Nile tilapia

\begin{tabular}{|c|c|c|c|c|c|c|c|}
\hline Item & $\mathbf{T}_{1}$ & $\mathbf{T}_{2}$ & $\mathbf{T}_{3}$ & $\mathbf{T}_{4}$ & $\mathbf{T}_{5}$ & $\mathbf{T}_{6}$ & SED \\
\hline Feed intake (g/fish) & 415.50 & 390.00 & 412.50 & 412.50 & 397.50 & 407.50 & 25.042 \\
\hline FCR & $2.88^{\mathrm{a}}$ & $2.42^{\mathrm{b}}$ & $2.42^{\mathrm{b}}$ & $2.38^{\mathrm{bc}}$ & $2.21^{\mathrm{bc}}$ & $2.15^{\mathrm{c}}$ & 0.094 \\
\hline PER & $1.15^{\mathrm{c}}$ & $1.37^{\mathrm{b}}$ & $1.37^{\mathrm{b}}$ & $1.39^{\mathrm{b}}$ & $1.50^{\mathrm{ab}}$ & $1.54^{\mathrm{a}}$ & 0.053 \\
\hline PPV, \% & $16.52^{c}$ & $20.01^{\mathrm{b}}$ & $20.37^{\mathrm{b}}$ & $20.40^{\mathrm{b}}$ & $22.15^{\mathrm{ab}}$ & $23.35^{\mathrm{a}}$ & 0.851 \\
\hline
\end{tabular}

Economic efficiency:

Data on economic efficiency performance are shown in Table (7). All diets indicated positive net returns and economic efficiency. $\mathrm{T}_{6}(2+2 \mathrm{ml}$ from ginger and licorice extract) demonstrated significantly $(P<0.05)$ higher net returns and economic efficiency than the other test diets while control diets $\mathrm{T}_{1}$ (without extracts) had significantly $(P<0.05)$ the least economic performance. Although net returns were positive for all the diets, there were significant differences in economic returns among the feeds. Mixed extracts was the most profitable compared with the other feeds. Despite the similarity in fish yields in groups received extracts, the net economic returns were lower in some diet because of the increased cost from the extracts.

Table (7): Effect of ginger and licorice extract on economic efficiency of Nile tilapia

\begin{tabular}{lccccccc}
\hline Item /hapa & $\mathbf{T}_{\mathbf{1}}$ & $\mathbf{T}_{\mathbf{2}}$ & $\mathbf{T}_{\mathbf{3}}$ & $\mathbf{T}_{\mathbf{4}}$ & $\mathbf{T}_{\mathbf{5}}$ & $\mathbf{T}_{\mathbf{6}}$ & $\mathbf{S E D}^{*}$ \\
\hline Feed Costs & 469.35 & 482.11 & 531.69 & 515.55 & 512.27 & 542.38 & 27.47 \\
Other costs & 100.00 & 100.00 & 100.00 & 100.00 & 100.00 & 100.00 & --- \\
Total cost & 569.35 & 582.11 & 631.69 & 615.55 & 612.27 & 642.38 & 27.47 \\
Total output & $581.45^{\mathrm{d}}$ & $655.15^{\mathrm{bc}}$ & $685.04^{\mathrm{cd}}$ & $718.20^{\mathrm{ab}}$ & $720.81^{\mathrm{ab}}$ & $783.30^{\mathrm{a}}$ & 18.03 \\
Net return & $12.10^{\mathrm{c}}$ & $73.04^{\mathrm{ab}}$ & $53.35^{\mathrm{c}}$ & $102.65^{\mathrm{ab}}$ & $108.55^{\mathrm{a}}$ & $140.92^{\mathrm{a}}$ & 17.71 \\
Economic efficiency $\%$ & $2.14^{\mathrm{c}}$ & $12.94^{\mathrm{ab}}$ & $8.45^{\mathrm{c}}$ & $16.68^{\mathrm{ab}}$ & $17.73^{\mathrm{a}}$ & $21.93^{\mathrm{a}}$ & 3.42 \\
\hline
\end{tabular}

* Average in the same row having different superscripts differ significantly $\mathrm{P} \leq 0.05$.

* SED is the standard error of difference

Price of $\mathrm{kg}$ feed $=8.9,9.4,9.9,9.4,9.9$ and 9.9 L.E. for diet 1, 2, 3, 4, 5 and 6 respectively

Price of one $\mathrm{kg}$ selling fish $=28$ L.E 
By commenting on the previous table, we can say that the addition of ginger and licorice extracts increased the cost of one $\mathrm{kg}$ of diet, but this was offset by a better weight gain which resulted in a reduction in the cost of gain. Economic efficiency results Equal or similar to (Al saiad and Al-Zayat, 2019). We can say that the recommended level of the inclusion is $2 \mathrm{ml} / \mathrm{kg}$ Ginger $+2 \mathrm{ml} / \mathrm{kg}$ licorice extracts feed and this choice is based on the nutritional parameters and economic analysis.

\section{CONCLUSION}

Medicinal herbal extracts provide useful biologically active metabolites with different benefits. Ginger (Zingiber Officinale) is one of the best known spices in the world it contains a wide array of bioactive compounds that can positively affect fish performance likewise Licorice extract which consider one of the herbal medicines commonly used for a number of purposes. Ginger and Licorice extracts was used with several levels, Based on the obtained results the Inclusion of ginger and licorice extracts in Nile tilapia diets have a positive effect on growth performance, feed utilization and economic efficiency beside improved water quality. Fish fed mixed diet (T6) achieved the best growth performance, feed utilization, higher net yields and economic efficiency compared with other tested diets and have a mitigating effect against heavy metal contamination in earthen ponds of Nile tilapia $(O$. niloticus).

\section{REFERENCES}

Abdel-Mohsien, H. S. and M. A. M. Mahmoud (2015). Accumulation of some heavy metals in Oreochromis niloticus from the Nile in Egypt: Potential hazards to fish and consumers. Journal of Environmental Protection, 06(09): 1003-1013.

Abumourad, I. M. K., M. M. N. Authman and W. T. Abbas (2013). Heavy metal pollution and metallothionein expression: A survey on Egyptian Tilapia farms. Journal of Applied Sciences Research, 9(1): 612-619.

Al saiad, S. M. and A. M. Al-Zayat (2019). Utilization of Ginger Extract in Nile Tilapia (Oreochromis niloticus) Diets. Egyptian Journal of Aquatic Biology and Fisheries, 23(4): 23-37.

Alm-Eldeen, A. A., T. Donia and S. Alzahaby (2018). Comparative study on the toxic effects of some heavy metals on the Nile Tilapia, Oreochromis niloticus, in the Middle Delta, Egypt. Environmental Science and Pollution Research, 25(15): 14636-14646.

Amar, E. C., M. J. S. Apines-Amar and J. P. Faisan (2018). Dietary onion or ginger modulates the stress response and susceptibility to Vibrio harveyi JML1 infection in brown-marbled grouper Epinephelus fuscoguttatus Juveniles. Journal of Aquatic Animal Health, 30(1): 3949.
AOAC (1995). Official methods of analysis of the Association of Official Analytical Chemists. $14^{\text {th }}$ ed. Arlington: AOAC; 3: 413.

Baltina, L. A. (2003). Chemical Modification of Glycyrrhizic Acid as A Route to New Bioactive Compounds for Medicine, Journal of Current Medicinal Chemistry, 10(2).

Braca, A., C. Sortino, M. Politi, I. Morelli and J. Mendez (2002). Antioxidant activity of flavonoids from Licania licaniaeflora Journal of Ethnopharmacology, 79(3): 379-381.

Brum, A., L. Cardoso, E. C. Chagas, F. C. M. Chaves, J. L. P. Mouriño and M. L. Martins (2018). Histological changes in Nile tilapia fed essential oils of clove basil and ginger after challenge with Streptococcus agalactiae. Aquaculture, 490: 98-107.

Cao, Z. F., Z. G. Chen, P. Guo, S. M. Zhang, L. X. Lian, L. Luo and W. M. Hu (1993). Scavenging effects of ginger on superoxide anion and hydroxyl radical. Chung-Kuo Chung Yao Tsa Chih, 18: 750-764.

Chen, C. C., D. Kolosov and S. P. Kelly (2015). Effect of the licorice root derivatives on salt and water balance in a teleost fish, rainbow trout (Oncorhynchus mykiss). Comparative Biochemistry and Physiology Part A: Molecular \& Integrative Physiology, 180: 8697.

Chen, C. C., D. Kolosov and S. P. Kelly (2016). The licorice root derivative glycyrrhetinic acid can ameliorate ionoregulatory disturbance in rainbow trout (Oncorhynchus mykiss) abruptly exposed to ion-poor water. Comparative Biochemistry and Physiology Part A, Molecular \& Integrative Physiology, 199: 120-129.

Damle, M. (2014). Glycyrrhiza glabra (Liquorice) a potent medicinal herb, International Journal of Herbal Medicine, 2(2): 132-136.

Dubey, M. K. and R. S. Anita (2018). Study of growth promoting and immunostimulatory effect of phytobiotic Glycyrrhiza glabra on fingerlings of Cyprinus carpio haematopterus. Indian Journal of Geo Marine Science, 47(06): 1180-1184.

Egwurugwu, J. N., C. S. Ufearo, O. C. Abanobi, C. R. Nwokocha, J. O. Duruibe, G. S. Adeleye and O. Onwufuji (2007). Effects of ginger (Zingiber officinale) on cadmium toxicity. African Journal of Biotechnology, 6: 20782082.

Elabd, H., H. P. Wang, A. Shaheen, H. Yao and A. Abbass (2016). Feeding Glycyrrhiza glabra (licorice) and Astragalus membranaceus (AM) alters innate immune and physiological responses in yellow perch (Perca flavescens). Fish \& Shellfish Immunology, 54: 374-384.

FAO (2018). Food and Agriculture Organization of the United Nations. The state of world fisheries and aquaculture. Rome, Italy: FAO.

Gabriel, N. N., J. Qiang, X. Y. Ma, J. He, P. Xu and K. Liu (2015). Dietary Aloe vera improves 
plasma lipid profile, antioxidant, and hepatoprotective enzyme activities in GIFTtilapia (Oreochromis niloticus) after Streptococcus iniae challenge. Fish Physiology and Biochemistry, 41(5): 13211332.

GAFRD (2018). General Authority for Fish Resource Development In: Fish statistics year book. Cairo Egypt. Ministry of Agriculture and land reclamation.

Gehan, A. E. and Y. A. Ayman (2010). Cadmium-ginger two way antagonistic relationship. Arab Journal of Biotechnology, 13(1): 115-124.

Gurkan, M., S. Yilmaz, H. Kaya, S. Ergun and S. Alkan (2015). Influence of three spice powders on the survival and histopathology of Oreochromis mossambicus before and after Streptococcus iniae infection. The Marine Science and Technology Bulletin, 4(1): 1-5.

Hamada, M. G., Z. H. Elbayoumi, R. A. Khader and A. R. M. Elbagory (2018). Assessment of heavy metal concentration in fish meat of wild and farmed Nile tilapia (Oreochromis niloticus), Egypt. Alexandria Journal of Veterinary Sciences, 57(1): 30-37.

Immanuel, G., R. P. Uma, P. Iyapparaj, T. Citarasu, S. M. Punitha Peter, M. Michael Babu and A. Palavesam (2009). Dietary medicinal plant extracts improve growth, immune activity and survival of tilapia Oreochromis mossambicus. Journal of Fish Biology, 74(7): 1462-1475.

Kalay, M. and M. Canli (2000). Elimination of Essential $(\mathrm{Cu}, \mathrm{Zn})$ and non-essential $(\mathrm{Cd}, \mathrm{Pb})$ metals from tissues of a freshwater fish Tilapia zilli. Turkish Journal of Zoology, 24(4): 429-436.

Kanani, H. G., Z. Nobahar, S. Kakoolaki and H. Jafarian (2014). Effect of ginger- and garlicsupplemented diet on growth performance, some hematological parameters and immune responses in juvenile Husohuso. Fish Physiology and Biochemistry, 40(2): 481-490.

Kaoud, H. A. and A. R. El-Dahshan (2010). Bioaccumulation and histopathological alterations of the heavy metals in Oreochromis niloticus fish. Nature and Science, 8(4): 147-156.

Khallaf, E. A., M. M. N. Authman and A. A. Alne-na-ei (2018). Contamination and ecological hazard assessment of heavy metals in freshwater sediments and Oreochromis niloticus (Linnaeus, 1758) fish muscles in a Nile River Canal in Egypt. Environmental Science and Pollution Research, 25(14): 13796-13812.

Lee, K.W., H. S. Kim, S. H. Cho, C. Park and M. Ha (2016). Effect of dietary inclusion of yacon, ginger and blueberry on growth, feed utilization, serum chemistry and challenge test against Streptococcus iniae of juvenile rockfish Sebastes schlegeli. Korean J. Fish. Aquat. Sci., 49: 823-829.

Mahdavi, M., A. Hajimoradloo and R. Ghorbani (2013). Effect of Aloe vera extract on growth parameters of common carp (Cyprinus carpio). World Journal of Medical Sciences, 9(1): 55-60.

Mohammed, E., M. Kamel, K. El Iraqi, A. M. Tawfik, M. S. Khattab and M. Elsabagh (2020). Zingiber officinale and Glycyrrhiza glabra, individually or in combination, reduce heavy metal accumulation and improve growth performance and immune status in Nile tilapia, Oreochromis niloticus. Aquaculture Research, 51(5): 1933-1941.

Niemiec, M. and B. Wiśniowska-Kielian (2015). Accumulation of manganese in selected links of food chains in aquatic ecosystems. Journal of Elementology, 20(4): 945-956.

NRC (1993). National Research Council, Nutrient Requirements of Fish. Committee on animal nutrition. Board on Agriculture. Washington, DC, USA: National Research Council National Academy Press; 114.

Nya, E. J and B. Austin (2009). Use of dietary ginger, Zingiber officinale Roscoe, as an immunostimulant to control Aeromonas hydrophila infections in rainbow trout, Oncorhynchus mykiss (Walbaum). J. Fish Dis., 32: 971-977.

Ogino, C. (1980). Requirements of carp and rainbow trout for essential amino acids. Bull. Jpn. Soc. Sci. Fish, 46: 171-174.

Olusola, S. E., B. O. Emikpe and F. E. Olaifa (2013). The potentials of medicinal plant extracts as bio-antimicrobials in aquaculture. International Journal of Medicinal and Aromatic Plants, 3(3): 404-412.

Prasad, S. and A. K. Tyagi (2015). Ginger and its constituents: role in prevention and treatment of gastrointestinal cancer. Review Article Gastroenterology Research and Practice, Article ID 142979, 11 pages.

Reverter, M., N. Bontemps, D. Lecchini, B. Banaigs and P. Sasal (2014). Use of plant extracts in fish aquaculture as an alternative to chemotherapy: current status and future perspectives. Aquaculture, 433: 50-61.

Shakya, S. R. (2015). Medicinal uses of ginger (Zingiber officinale Roscoe) improves growth and enhances immunity in aquaculture. International Journal of Chemical Studies, 3(2): 83-87.

Shaluei, F., A. Nematollahi, H. R. Naderi-Farsani, R. Rahimi and J. K. Katadj (2016). Effect of ethanolic extract of Zingiber officinale on growth performance and mucosal immune responses in rainbow trout (Oncorhynchus mykiss). Aquaculture Nutrition, 23(4): 814-821.

Siegel, R., C. Desantis and A. Jemal (2014). "Colorectal cancer statistics, 2014,” CA Cancer Journal for Clinicians, 64(2): 104-117.

Sirakov, I., K. Velichkova, S. Stoyanova and Y. Staykov (2019). Growth performance biochemical blood parameters and meat quality of rainbow trout (oncorrhynchus mykiss W.) Feed with licorice (Glycyrrhiza 
glabra L.) supplemented. Trakia Journal of Sciences, 4: 284-291.

Smith, N. C., S. L. Christian, R. G. Taylor, J. Santander and M. L. Rise (2018). Immune modulatory properties of 6-gingerol and resveratrol in Atlantic salmon macrophages. Molecular Immunology, 95: 10-19.

Sukumaran, V., S. C. Park and S. S. Giri (2016). Role of dietary ginger Zingiber officinale in improving growth performances and immune functions of Labeo rohita fingerlings. Fish \& Shellfish Immunology, 57: 362-370.

Talpur, A. D., M. Ikhwanuddin and A. M. Ambok Bolong (2013). Nutritional effects of ginger (Zingiber officinale Roscoe) on immune response of Asian sea bass, Lates calcarifer (Bloch) and disease resistance against Vibrio harveyi. Aquaculture, 400: 46-52.

Tiwari, R., S. K. Latheef, I. Ahmed, H. M. N. Iqbal, M. H. Bule, K. Dhama and M. R. Farag (2018). Herbal Immunomodulators a remedial panacea for designing and developing effective drugs and medicines: Current scenario and future prospects. Current Drug Metabolism, 19(3): 264-301. https://doi.org/10.2174/1389200219666180129125436

Yang, X., J. L. Guo, J. Y. Ye, Y. X. Zhang and W. Wang (2015). The effects of Ficus carica polysaccharide on immune response and expression of some immunerelated genes in grass carp, Ctenopharyngodon idella. Fish \& Shellfish Immunology, 42(1): 132-137.

Y1lmaz, S and S. Ergün (2018). Trans-cinnamic acid application for rainbow trout (Oncorhynchus mykiss): I. Effects on haematological, serum biochemical, non-specific immune and head kidney gene expression responses. Fish \& Shellfish Immunology, 78: 140-157.
Yilmaz, S. (2019a). Effects of dietary blackberry syrup supplement on growth performance, antioxidant, and immunological responses, and resistance of Nile tilapia, Oreochromis niloticus to Plesiomonas shigelloides. Fish \& Shellfish Immunology, 84: 1125-1133.

Yilmaz, S. (2019b). Effects of dietary caffeic acid supplement on antioxidant, immunological and liver gene expression responses, and resistance of Nile tilapia, Oreochromis niloticus to Aeromonas veronii. Fish \& Shellfish Immunology, 86: 384-392.

Yilmaz, S., S. Ergün, H. Kaya and M. Gürkan (2014). Influence of Tribulus terrestris extract on the survival and histopathology of Oreochromis mossambicus (Peters, 1852) fry before and after Streptococcus iniae infection. Journal of Applied Ichthyology, 30(5): 994-1000.

Yin, G., L. Cao, P. Xu, G. Jeney, M. Nakao and C. Lu (2011). Hepatoprotective and antioxidant effects of Glycyrrhiza glabra extract against carbon tetrachloride $(\mathrm{CCl}(4))$-induced hepatocyte damage in common carp (Cyprinus carpio). Fish Physiology and Biochemistry, 37(1): 209-216.

Zanuzzo, F. S., E. C. Urbinati, M. L. Rise, J. R. Hall, G. W. Nash and A. K. Gamperl (2015). Aeromonas salmonicida induced immune gene expression in aloevera fed steelhead trout, Oncorhynchus mykiss (Walbaum). Aquaculture, 435: 1-9.

Zhang, P., X. Zhang, J. Li and T. Gao (2010). Effect of refeeding on the growth and digestive enzyme activities of Fenneropenaeus chinensis juveniles exposed to different periods of food deprivation. Aquaculture International, 18(6): 1191-1203. 